INOBIS: Jurnal Inovasi Bisnis dan Manajemen Indonesia

Volume 4, Nomor 1, Bulan Desember 2020

Sri Hermuningsih, Pristin Prima Sari, Annisa Dewi Rahmawati

\title{
The Impact of Leverage on Investment for Firms Listed in the Indonesian Stock Exchange
}

\author{
Sri Hermuningsih \\ University of Sarjanawiyata Tamansiswa \\ Pristin Prima Sari \\ University of Sarjanawiyata Tamansiswa \\ Anisya Dewi Rahmawati \\ University of Sarjanawiyata Tamansiswa \\ hermun_feust@yahoo.co.id
}

\begin{abstract}
Food and beverage firms listed in Indonesia Stock Exchange (IDX) that have opportunities to grow and develop and predicted to be improved. Food and beverage firms needed by mankind because of basic ingredient. Food and beverage firms engaged in manufacturing products and ordering to obtain large profits. Achieving these objectives, management need high level of effectiveness that is required. Firm management faced by various kinds of corporate financial decisions, one of which is investment decisions. Investment decision must consider factors such as the leverage ratio. The main adjective is to examine and obtain evidence about the impact of leverage on investment decisions in a food and beverage firm listed on the Indonesian Stock Exchange. The study used a quantitative approach with purposive sampling technique. The population used in this study were food and beverage firms from 2015 to 2019. The TKT achievement was TKT 6. The results have finding that leverage with the DAR proxy have a significant positive impact on investment. The greater the leverage, the greater the firm's investment. Research have beneficial for firm shareholders who consider their investment, and also for firm management for developing corporate leverage and investment.
\end{abstract}

Keywords: Leverage, and investment decisions

\section{Research Background}

Economic growth definited by firm management for gaining more effective and efficiently in firm stability and survival in business competition, especially for firms listed in capital market. Firm management conducted by maximize the welfare of shareholders through the authority given to make decisions which include investment decisions. Competition in emerging market encourage better business strategic for survive or becoming market leader. Investment project will be main important in that competition. Investment project included in plant, property and equipment that is developing research and development programme. Investment make important economic activity in financial management. Investment decision obtained in the future production of goods and services, expansion of market share, profit and so on. Tandelilin (2011) Investment decisions determined funds and resources for future benefits. A Lack of investment decisions strengthen worse performance and market value. The higher growth indicated better investment opportunity.

There were different ways to gaining investment project such as funding decision. Funding decision contains debt and equity. Firm management have several choices and reason 


\section{Sri Hermuningsih, Pristin Prima Sari, Annisa Dewi Rahmawati}

for debt and equity. Funding from debt expected have positive impact on investment project. Increasing debt is expected to gaining better firm performance.

Leverage contains comparation of debt and asset. The higher leverage is the greater of risk and the greater of profit that is expected. Leverage determined whether the investment will use capital originating from within the firm (eg cash, profit) or use sources of capital from outside the firm, namely debt. Funding decisions are used for corporate investment activities (Hanafi, 2016). Financial leverage is a component of debt, stock equity and preferred stock that is used to finance the firm's total assets, operations and financial growth (Goel et al., 2015). Firms can hold small amounts of cash and use the funds obtained from debt for firm investments, so that the relationship between debt policy and firm investment is positive. Wijaya and Murwani (2011) show that leverage has a positive effect on investment decisions. Based on the background of the problem, the researcher conducted a study on The impact of leverage on investment in firms listed on the Indonesian stock exchange.

The main interest of study is that we provide some findings in impacts of investment decisions on food and beverage firms listed in the Indonesian stock exchange. The Main Adjective of this study is to identify what investment decisions are in food and beverage firms listed on the Indonesian stock exchange. The research benefits, among others, are for investors, being able to find out the investment opportunities that exist within each firm and choosing the right firm to invest their capital, especially to determine the issuer's tendency to make investment decisions, for the firm to provide additional information and can be used as consideration. in determining investment decisions to be taken, for further research for reference in producing reference sources related to investment decisions.

This study organized as follows. In the first section, we collect difference empirical studies in leverage and investment. In the second section, we make line previous studies and theory, and how it can influence future investment opportunity, then how it can apply to empirical studies. We follow with a description of our methodology, and then discussion our findings. We subsequently interpret our case findings in terms of leverage and investment opportunity, and strengthen on existing theories.

\section{Literature Review Agency Theory}

Agency theory showed the management as the agent and the shareholder as the principal builds a cooperation contract to gain high profit for stockholders (Fahmi, 2014: 19). Agency theory included agency cost because of different interest between management and stockholders. Stockholder must control management action by gaining commisaris independent or managerial ownership that called agency cost.

\section{Capital Structure Theory}

Ross (1977) in Hanafi (2008) found signalling theory that debt have positive signal for market in developing business. Trade off theory found that debt ratio have bankcruptcy cost and tax saving. Pecking order theory found that internal funding is a better choice than ecternal funding. Internal funding such as retained earning and stock ownership. MM Theory stated that leverage firms and unleverage firms have same value without tax (Hanafi, 2008). 


\section{Food and beverage firms}

Food and beverage firms have large opportunities to grow and sustain. Food and beverage firms included consumer goods sector in IDX which have high competitive advantages and better investment decision than other sectors. Food and beverage sectors tend to have lower risk than others.

\section{Investment Decisions}

An investment decision showed a better investment opportunity in the future benefits. Investors make investment in real assets or capital market. Herdiyanti (2018) found that Investment make an effort to gain the wealth in future. The investment objective created a sustainability in investment, maximum profit, prosperity for shareholders and contribute to the development of the nation. However, Fahmi (2014) showed several steps that must be taken in investing, namely 1) setting investment targets; 2) making investment policies; 3) choosing a portfolio strategy; 4) selecting assets; and 5) measuring and evaluating performance. This study presents investment decisions by using firm capital to gain firm assets which include current assets, fixed assets and other assets thus increase firm productivity and profits.

Nurcahyani and Suardhika (2017) found the investment formula using the Investment Opportunity Set (IOS) with a proxy for fixed assets to total assets. Hidayah (2015) using the Investment opportunity Set (IOS) with investment to net sales. So this study uses the measurement of investment variables with IOS with investment to net income as a proxy.

Table 1 Previous Researchs

\begin{tabular}{|c|c|c|c|}
\hline No & Researchers & Results & Variable \\
\hline 1. & $\begin{array}{ll}\text { Moeljono } & \text { and } \\
\text { Alfianto (2020) }\end{array}$ & $\begin{array}{l}\text { investment opportunity set (IOS) and } \\
\text { leverage have positive impact on cash } \\
\text { dividend }\end{array}$ & $\begin{array}{l}\text { IOS }=\text { Market to book } \\
\text { value }\end{array}$ \\
\hline 2. & $\begin{array}{l}\text { Santosa, } \\
\text { Jumaedi, } \\
(2020)\end{array}$ & $\begin{array}{l}\text { Investment have impact on advantage } \\
\text { value batik industry center }\end{array}$ & $\begin{array}{l}\text { Return Investasi -> } \\
\text { NPV }=[\text { Present value } \\
\text { of benefits }]-[\text { Value } \\
\text { of investments }]\end{array}$ \\
\hline 3. & Myers (1984) & $\begin{array}{l}\text { IOS Myers (1984) is combination } \\
\text { between activa (assets in place) } \\
\text { and future investment }\end{array}$ & $\begin{array}{l}\text { Fixed Aktiva } \\
\text { investment } \\
\text { opportunity }\end{array}$ \\
\hline 4. & $\begin{array}{l}\text { Bismark, Pasaribu } \\
\text { Dan Kowanda (2013) }\end{array}$ & $\begin{array}{l}\text { Bismark, Pasaribu Dan Kowanda } \\
\text { (2013) found that Leverage, } \\
\text { profitability and likuidity as a } \\
\text { determination funding decision that } \\
\text { impact on growth called investment } \\
\text { opportunity set (IOS). }\end{array}$ & $\begin{array}{l}\text { Growth }=\text { investment } \\
\text { opportunity set }(\mathrm{IOS}) \text {. }\end{array}$ \\
\hline 5. & $\begin{array}{l}\text { Pertiwi, Tommy, } \\
\text { Tumiwa (2016) }\end{array}$ & $\begin{array}{l}\text { Pertiwi, Tommy, Tumiwa (2016) used } \\
\text { PER for investment opportunity set } \\
\text { (IOS). }\end{array}$ & $\begin{array}{l}\text { Investment } \\
\text { opportunity set (IOS) } \\
=\text { price to earning } \\
\text { ratio (PER) }\end{array}$ \\
\hline
\end{tabular}


INOBIS: Jurnal Inovasi Bisnis dan Manajemen Indonesia

Volume 4, Nomor 1, Bulan Desember 2020

Sri Hermuningsih, Pristin Prima Sari, Annisa Dewi Rahmawati

\begin{tabular}{|c|c|c|c|}
\hline No & Researchers & Results & Variable \\
\hline 6. & Sandiar (2017) & $\begin{array}{l}\text { Sandiar (2017) found that leverage } \\
\text { and debt maturity have negative } \\
\text { impact on investment decision, thus } \\
\text { growth opportunities have positive } \\
\text { impact on investment decision. } \\
\text { growth opportunities does not } \\
\text { moderate on leverage and investment } \\
\text { decision, then growth opportunities } \\
\text { have moderation debt maturity on } \\
\text { investment decision. }\end{array}$ & $\begin{array}{l}\text { Investment }=\text { Net } \\
\text { Investment/(Fix asset } \\
\mathrm{t}-\text { Fix asset } \mathrm{t}-1) \text { And } \\
\text { Growth Opportunity } \\
\text { used Tobin-Q }\end{array}$ \\
\hline
\end{tabular}

Sources : articles of journal

\section{Leverage}

Leverage contain the ability using assets or funds to gain fixed expenses. The greater the level of leverage indicates that the greater the risk that must be borne by the firm and the greater the level of profit that is expected to be obtained by the firm. The leverage ratio used in this study is Debt to Asset Ratio (DAR), this is because this ratio is a ratio that compares debt to assets, where investment decisions are decisions to purchase assets so that there is compatibility between the two variables. Based on the value of the Debt Assets to Ratio (DAR), it can also be seen how much assets are financed by debt and to determine further investment whether to use debt as a source of capital. Sandiar (2017) found that leverage have negative effect on investment opportunities.

\section{Hypothesis of the Impact of Leverage on Investment}

Leverage is a source of firm funding that can be used for firm investment. Sources of funds used for profitable investment can increase the firm's assets. The greater the source of funds the firm gets, the greater the opportunity for the firm to invest. Wijaya and Murwani (2011) that leverage has a positive effect on investment. Thus, the research hypothesis is as follows:

Hypothesis: Leverage has a significant positive effect on investment.

\section{Theoretical Framework}

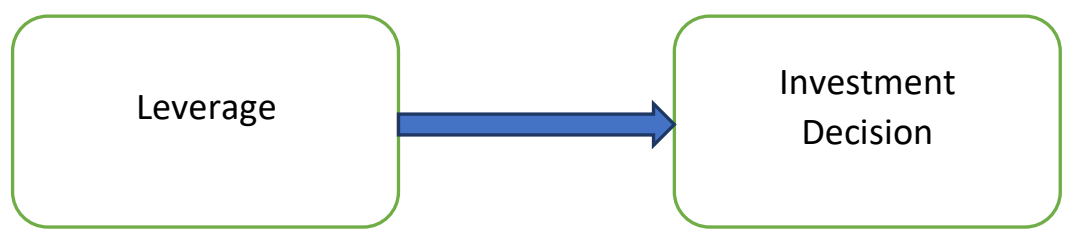

Figure 1 Theoritical Framework (Wijaya and Murwani, 2011) 
INOBIS: Jurnal Inovasi Bisnis dan Manajemen Indonesia

Volume 4, Nomor 1, Bulan Desember 2020

Sri Hermuningsih, Pristin Prima Sari, Annisa Dewi Rahmawati

\section{Research Methodology}

\section{Research design}

The study uses quantitative method with statistic analysis. Our study collected annual financial statement data from food and beverage firms listed in Indonesia Stock Exchange in period 2015-2019. They were AISA, ICBP, INDF, MYOR, PSDN, ROTI, SKBM, SKLT, STTP, and ULTJ.

\section{Data And Technique Sampling}

The study used purposive sampling method, namely the technique of determining the sample by using certain criteria (Sugiyono, 2012: 122). The sample criteria in this study are food and beverage firms that have a complete report for the period 2015 to 2019. Based on these criteria, there are 10 samples from the food and beverage firm. The data in this study are secondary data, in the form of leverage and investment decisions.

\section{Research Variables}

The dependent variable is the variable that is affected or that is the result, because of the independent variable. The dependent variable in this study is investment decisions using the Investment Opportunity Set (IOS) proxy (Hidayah, 2015).

$$
\begin{aligned}
& \text { Invesment to net sales }=\text { Investasi } \\
& \text { Net Sales } \\
& \text { Or } \\
& \text { Invesment to net sales }=\text { Investasi } \\
& \text { Income }
\end{aligned}
$$

\section{Independent variable}

Independent variable is variable that affect or cause changes or the emergence of the dependent variable. The independent variable in this study is leverage using a proxy debt to total assets (DTA) by Goel (2015).

$\begin{aligned} \text { Debt to total asset }=\quad \text { Debt } & \ldots . .(2) \\ & \text { Total asset }\end{aligned}$

\section{Data Analysis Techniques}

Data management in this study will be processed using the Microsoft Excel program, Statistical Package for Social Sciences (SPSS) 18. Descriptive statistical test is used to determine the impact of leverage on investment decisions in food and beverage firms listed on the Indonesian Stock Exchange. The classical assumption test is a test used to determine whether the multiple regression model used in this study meets the classical assumption or not. 
The classical assumption tests used are: normality test, multicollinearity test, heteroscedasticity test and autocorrelation test. The Regression Equation as follows :

$\mathrm{Yi}=\alpha+\beta 1 \mathrm{X} 1+\mathrm{e}$

Information :

$\mathrm{Yi}=$ The dependent variable of firm I's investment decision in period $\mathrm{t}$

$\alpha=$ constant

$1=$ the independent variable leverage

$\beta 1,=$ parameter $/$ regression coefficient

$\mathrm{e}=$ error term

\section{Results And Discussion}

\section{Statistic Deskriptive}

The study produced 60 observational data from 10 firms on the Indonesia Stock Exchange in 2019-2014. The variables used are leverage as proxied by debt to total assets (DAR) and Investment Opportunity Set (IOS) using investment to income as a proxy.

Table 2 shows that the average leverage value is $51.6 \%$ and IOS $47.7 \%$, the maximum leverage value is 2.89 and IOS $93 \%$, while the minimum leverage value is $14 \%$ and IOS is $48.5 \%$. The negative IOS number was obtained because there were firms that suffered losses in the observation year.

Table 2. Statistic Descriptive

\begin{tabular}{lccccc}
\hline & N & Minimum & Maximum & \multicolumn{1}{l}{ Mean } & \multicolumn{1}{l}{ Std. Deviation } \\
& Statistic & \multicolumn{1}{c}{ Statistic } & \multicolumn{1}{c}{ Statistic } & \multicolumn{1}{c}{ Statistic } & \multicolumn{1}{c}{ Statistic } \\
\hline DAR & 60 & .1400 & 2.8900 & .516167 & .3844216 \\
Investoincome & 60 & -.4858 & .9399 & .477174 & .2683643 \\
Valid N (listwise) & 60 & & & & \\
\hline
\end{tabular}

Source : SPSS processed (2020)

\section{Classical Assumption Test Results}

\section{1) Normality Test}

Normality test using the histogram image figure 2. Figure 2 shows that the sample data is normality. Santosa (2008) stated that Balancing histogram means normality. 


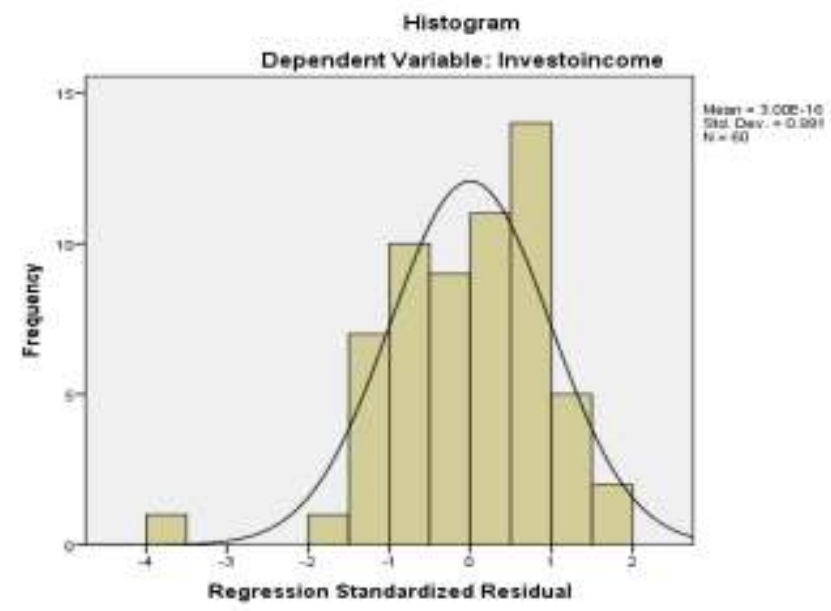

Figure 2 Histogram Normality(SPSS,2020)

\section{Heteroskedastisity Test}

Heteroskedastisity test using scatterplot in figure 3. Figure 3 show that scatterplot spread means heteroskedastisity. Santosa (2008) stated that scatterplot spread thus data becomes heteroskedastisity.

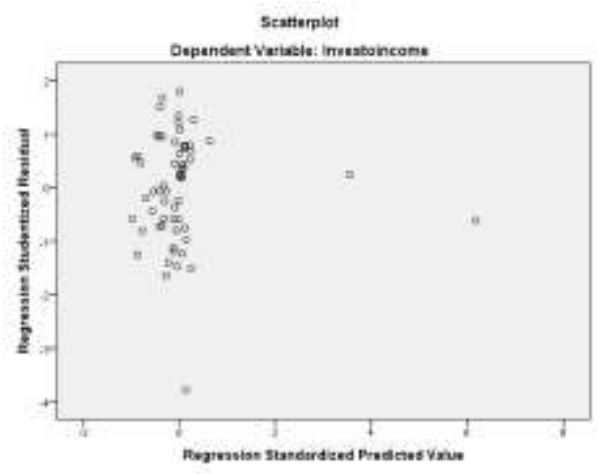

Figure 3 Scatterplot Heteroskedastisity(spss,2020)

\section{Autocorelation Test}

The autocorrelation test uses the Durbin-Watson results that the DW value shows the number 1.848. According to Santosa (2008) the autocorrelation-free value is the DW -2 to + 2. Then the results of the study the DW value is $1.848<2$ thus the sample data is free of autocorrelation. Durbin Watson Results in Table 5.

\section{Multicoleration}

Multicorrelation test using VIF value. The VIF value and tolerance are 1. VIF value show in table 7. Table 3 show that correlation value is 0,281 means positive sufficient value (Sarwono, 2011). Positive correlation means one way correlation between leverage and investment. If leverage increase thus investment will increase. 
INOBIS: Jurnal Inovasi Bisnis dan Manajemen Indonesia

Volume 4, Nomor 1, Bulan Desember 2020

Sri Hermuningsih, Pristin Prima Sari, Annisa Dewi Rahmawati

Table 3 Correlations

\begin{tabular}{llrr}
\hline & & Investoincome & \multicolumn{1}{c}{ DAR } \\
\hline Pearson Correlation & Investoincome & 1.000 & .281 \\
& DAR & .281 & 1.000 \\
& Investoincome &. & .015 \\
Sig. (1-tailed) & DAR & .015 &. \\
& Investoincome & 60 & 60 \\
$\mathrm{~N}$ & DAR & 60 & 60 \\
& &
\end{tabular}

Source : spss processed (2020)

Table 4 Collinearity Diagnostics ${ }^{\mathrm{a}}$

\begin{tabular}{llrrrr}
\hline & & & Condition & \multicolumn{2}{c}{ Variance Proportions } \\
Model & Dimension & Eigenvalue & \multicolumn{1}{c}{ Index } & (Constant) & DAR \\
\hline 1 & 1 & 1.804 & 1.000 & .10 & .10 \\
& 2 & .196 & 3.037 & .90 & .90 \\
\hline
\end{tabular}

a. Dependent Variable: Investoincome

\section{Result of the coefficient of determination}

Table 5 shows the results of the coefficient of determination using the adjusted R square number. The value of Adjusted $\mathrm{R}$ square of $6.3 \%$ means that the leverage variable can affect the investment variable by $6.3 \%$, while $94.7 \%$ of the investment variable is influenced by variables outside the research model.

Table 5 Model Summary

\begin{tabular}{rrrrrr}
\hline Model & R & R Square & \multicolumn{1}{c}{$\begin{array}{c}\text { Adjusted R } \\
\text { Square }\end{array}$} & $\begin{array}{l}\text { Std. Error of } \\
\text { the Estimate }\end{array}$ & \multicolumn{1}{c}{$\begin{array}{l}\text { Durbin- } \\
\text { Watson }\end{array}$} \\
\hline 1 & $.281^{\mathrm{a}}$ & .079 & .063 & .2597726 & 1.848 \\
\hline
\end{tabular}

a. Predictors: (Constant), DAR

b. Dependent Variable: Investoincome

\section{F Test Results}

The $\mathrm{F}$ test answers the relationship simultaneously or jointly between variables. Table 6 shows that the $F$ number is 4,967 and a significance value of 0.03 means that the leverage 
variable (DAR) has a significant positive effect on investment. The significance value of 0.03 is less than 5\%, so leverage has a significant impact on investment. The greater the leverage, the greater the firm's opportunity to invest. Firm debt is used for investment activities.

Table 6 ANOVA

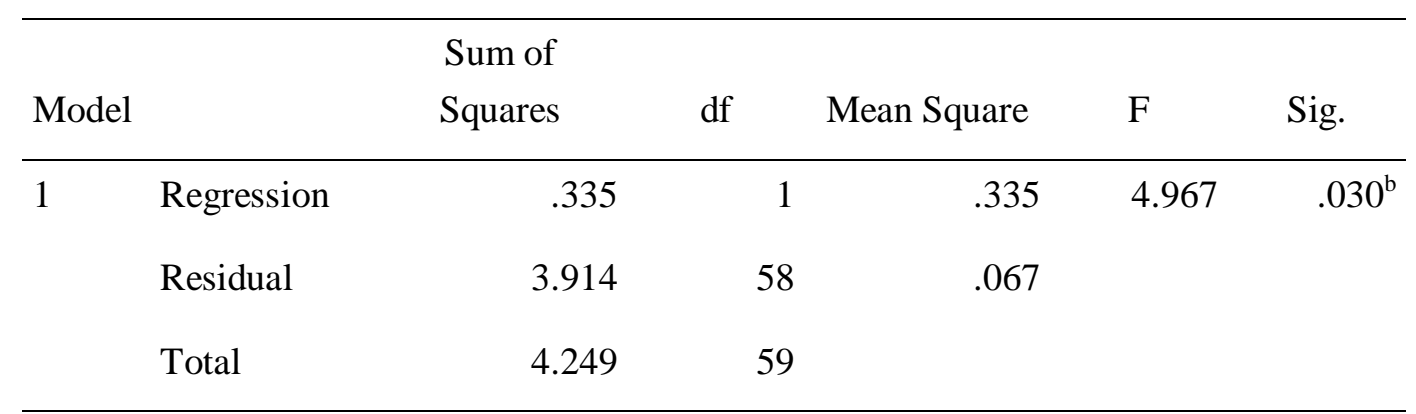
a. Dependent Variable: Investoincome
b. Predictors: (Constant), DAR

\section{The Results of Hypothesis (t-test)}

Hypothesis test used t test to solve problems and answers research objective. The results showed that leverage have significant effect on investment. Table 7 showed $t$ value is 2,229 and probability is 0,030 that leverage is significant influence to investment. The formula of regression as follow in table 7 which is $\mathrm{Y}=0,376+0,281 \mathrm{DAR}+\mathrm{e}$.

\section{Table $7 \mathrm{t}$ test $\left(\right.$ Coefficients $^{\mathrm{a}}$ )}

\begin{tabular}{|c|c|c|c|c|c|c|c|c|}
\hline \multirow{2}{*}{\multicolumn{2}{|c|}{ Model }} & \multicolumn{2}{|c|}{$\begin{array}{l}\text { Unstandardized } \\
\text { Coefficients }\end{array}$} & \multirow{2}{*}{$\begin{array}{c}\text { Standardized } \\
\text { Coefficients } \\
\text { Beta }\end{array}$} & \multirow[b]{2}{*}{$\mathrm{t}$} & \multirow[b]{2}{*}{ Sig. } & \multicolumn{2}{|c|}{$\begin{array}{l}\text { Collinearity } \\
\text { Statistics }\end{array}$} \\
\hline & & B & Std. Error & & & & Tolerance & VIF \\
\hline \multirow[t]{2}{*}{1} & (Constant) & .376 & .056 & & 6.660 & .000 & & \\
\hline & DAR & .196 & .088 & .281 & 2.229 & .030 & 1.000 & 1.000 \\
\hline
\end{tabular}

a. Dependent Variable: Investoincome

\section{Discussion}

The study found that leverage with the proxy debt to total assets (DAR) have a significant positive effect on investment. The firm's leverage that comes from debt can have an impact on the firm's investment. Firm debt is used for firm investment. The bigger the firm's debt, the greater the firm's investment opportunity. The research sample firms show that the debt held is proportional to the investment used. The results of the study are the same as the hypothesis so that the research hypothesis is accepted. This study is the same as Wijaya and Murwani's research (2011) where debt has a good impact on investment. 
INOBIS: Jurnal Inovasi Bisnis dan Manajemen Indonesia

Volume 4, Nomor 1, Bulan Desember 2020

Sri Hermuningsih, Pristin Prima Sari, Annisa Dewi Rahmawati

Based on table 4.6, the research implication is that leverage has a good impact on investment decisions. Leverage encourages increased investment decisions.

Table 8. Hypothesis Results

\begin{tabular}{llll}
\hline Hyphotesis & Sig & Note & Implication \\
\hline Leverage -> Investment Decision & 0,030 & Accepted & $\begin{array}{l}\text { Leverage have positive impact } \\
\text { on investment decision }\end{array}$
\end{tabular}

Source : spss processed (2020)

\section{Conclusion}

The study provide finding that leverage has a significant positive effect on investment of consumer sector in Indonesia Stock Exchange. Investment funding source comes from financial leverage. Financial leverage means debt or external funding. The bigger the debt thus the bigger the firm's investment.

\section{Suggestions}

The firm takes advantage of the leverage from debt for investment opportunities so that the firm's income will also increase. We recommend that firms minimize losses due to tax payments because the losses recorded by the firm come from after tax income. Firm management take control cost of debt in leverage funding decision for valuable investment.

\section{Research Limitations}

This study uses measurement variables and a limited number of samples and variable thus it cannot find the overall impact on firm investment. We provide findings in the limited time of observations. The more variable maybe will find more findings.

\section{Aknowledgement}

1. Community service of Sarjanawiyata Tamansiswa University

2. Economic student of Sarjanawiyata Tamansiswa University

\section{Daftar Pustaka}

Bismark, Rowland; Fernando Pasaribu Dan Dionysia Kowanda. (2013). Kesempatan Investasi Dan Determinan Kebijakan. Pendanaan Perusaahaan Publik Indonesia. Akrual 5 (1) (2013): 1-25 e-ISSN: 2502-6380, http://fe.unesa.ac.id/ojs/index.php/akrl

Fahmi, Irham. (2014). Teori Portofolio Dan Analisis Investasi. Bandung: Alfabeta

Goel, Utkarsh et al. (2015) . Operating liquidity and financial leverage: Evidences from Indian machinery industry. Procedia - Social and Behavioral Sciences 189 ( 2015 ) $344-350$.

Hanafi, Mamduh. (2016). Manajemen Keuangan Edisi 2. Yogyakarta : BPFE Yogyakarta

Herdianti Wiwit, Husaini A. (2018) . Pengaruh Leverage, Kepemilikan Manajerial Dan Kepemilikan Institusional Terhadap Keputusan Investasi (Studi Pada Perusahaan 
Sektor Industri Barang Konsumsi Yang Terdaftar Di Bursa Efek Indonesia Periode 2010-2016). Jurnal Administrasi Bisnis (JAB. Vol. 55 No. 2.

Lang, L.H.P., Ofek, E., Stulz, R.M. (1996). Leverage, Investment, And Firm Growth. Journal Of Financial Economics 40, 3-29.

Moeljono Dan Alfianto, Nasron. (2020). Peran Size Dalam Memoderasi Pengaruh Profitabilitas, Invesment Oppourtunity Set Dan Leverage Terhadap Kebijakan Dividend. Jurnal Ekobis Unisula, Vol 11, No 1 Januari (2020)

Pertiwi, Putri Juwita; Tommy, Parengkuan; Dan Tumiwa, Johan R. Pengaruh Kebijakan Hutang, Keputusan Investasi Dan Profitabilitas Terhadap Nilai Perusahaan Food Andbeverages Yang Terdaftar Di Bursa Efek Indonesia. Jurnal EMBA Vol.4 No.1 Maret 2016, Hal. 1369-1380. Jurnal Riset Ekonomi, Manajemen, Bisnis dan Akuntansi, https://media.neliti.com/media/publications/3007-ID-pengaruh-kebijakan-hutangkeputusan-investasi dan-profitabilitas-terhadap-nilai.pdf

Sandiar, Loecita (2017). Growth Opportunity Dalam Memoderasi Pengaruh Leverage Dan Debt Maturity Terhadap Keputusan Investasi. Journal of Applied Business and Economics Vol. 3 No. 4 (Jun 2017) 196-206.

Santoso, Meilanny Budiarti; Raharjo, Santoso Tri; Humaedi, Sahadi Dan Mulyono, Hendri.(2020). Social Return On Investment (Sroi) Program "Sentra Industri Bukit Asam” (Siba) Batik Kujur Village Tanjung Enim. AdBispreneur : Jurnal Pemikiran dan Penelitian Administrasi Bisnis dan Kewirausahaan Vol.5, No. 1, April 2020, DOI : https://doi.org/10.24198/adbispreneur.v5i1.26069, hal. 15-29

Santosa, Singgih. (2008). SPSS Statistik Multivariat. Jakarta : PT.Elex Media Komputindo

Sarwono, Jonathan. (2011). Analisis Jalur untuk Riset Bisnis dengan SPSS. Yogyakarta : ANDI.

Sugiyono. (2012). Metode Penelitian Kuantitatif Kualitatif Dan R\&D. Bandung: Alfabeta.Hal 122

Tandelilin, Eduardus. (2011). Analisis Investasi dan Manajemen Portofolio. Yogyakarta:Kanisius

Wijaya, Langgeng Anggita Dan Murwani, J.(2011). "Pengaruh Kepemilikan Manajerial, Leverage Dan Profitabilitas Terhadap Kebijakan Investasi Perusahaan".Jurnal Dinamika Akuntansi. Vol. 3(1): Pp. 33-41.311-318. 